Volume 3

Number 1 Critical Perspectives on Marketing

from Japan - Part 1

2018

\title{
Japan and Critical Marketing Theory: Opening a Window
}

Masaaki Takemura

Meiji University

Nikhilesh Dholakia

University of Rhode Island

Follow this and additional works at: https://digitalcommons.uri.edu/mgdr

Part of the Anthropology Commons, Economics Commons, Marketing Commons, Other Business Commons, and the Sociology Commons

\section{Recommended Citation}

Takemura, Masaaki and Dholakia, Nikhilesh (2018) "Japan and Critical Marketing Theory: Opening a Window," Markets, Globalization \& Development Review. Vol. 3: No. 1, Article 1.

DOI: 10.23860/MGDR-2018-03-01-01

Available at: https://digitalcommons.uri.edu/mgdr/vol3/iss1/1

This Editorial is brought to you for free and open access by DigitalCommons@URI. It has been accepted for inclusion in Markets, Globalization \& Development Review by an authorized editor of DigitalCommons@URI. For more information, please contact digitalcommons-group@uri.edu. 


\section{Japan and Critical Marketing Theory: Opening a Window}

\section{Cover Page Footnote}

The core ideas in this editorial are from the first editor. The second editor has provided general background and English language editing. 


\section{Markets, Globalization \& Development Review}
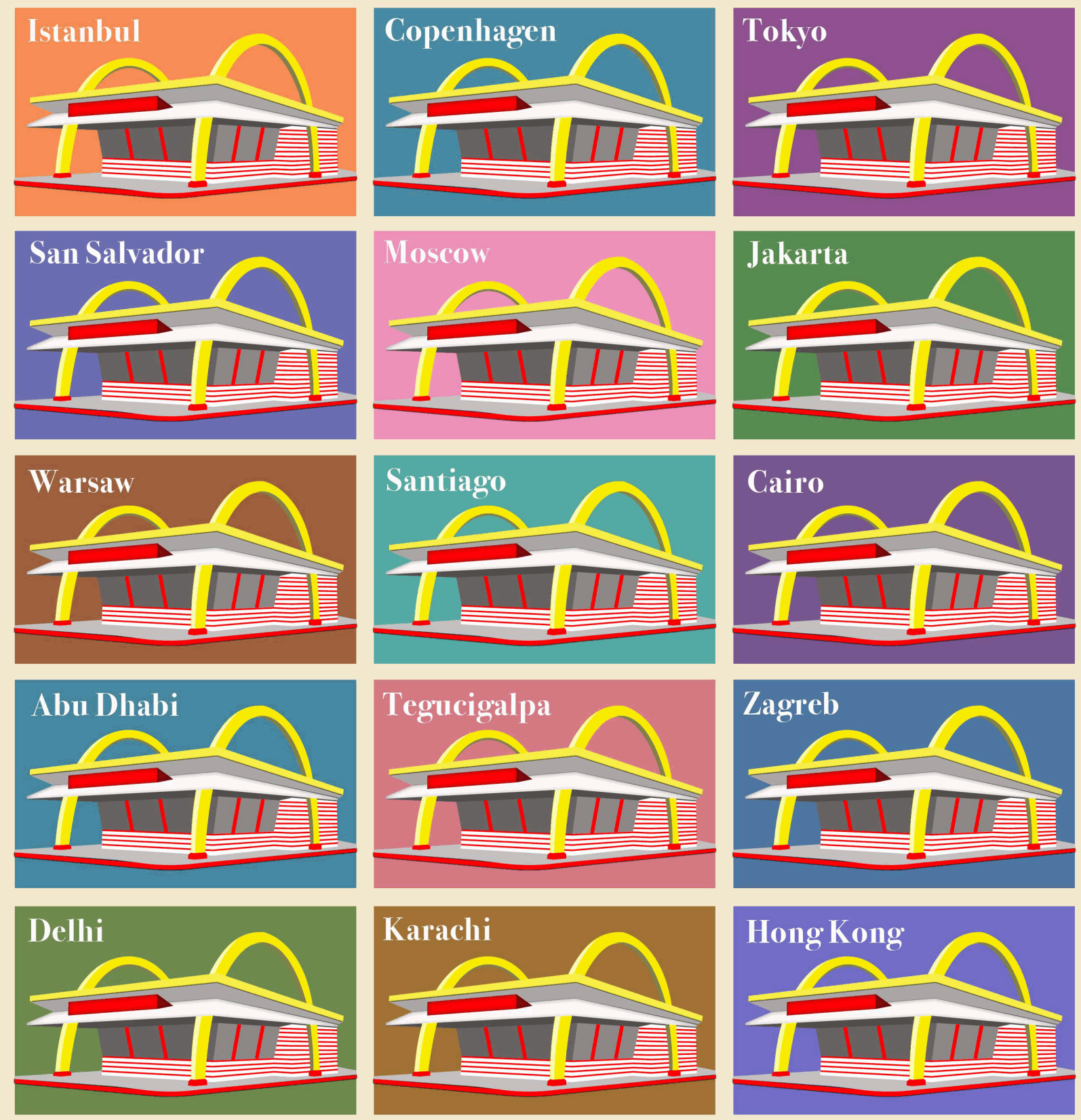

This editorial is available in Markets, Globalization \& Development Review: https://digitalcommons.uri.edu/mgdr/ vol3/iss $1 / 1$ 


\section{Japan and Critical Marketing Theory: Opening a Window}

\section{Introduction}

Critically oriented writing about marketing topics has a fairly long tradition in Japan. Such writing is almost always in the Japanese language, and hence unknown to readers and researchers outside Japan. The time for bringing some of the critical marketing perspectives from Japan into a wider light, via writings in English language, is long overdue. With this special issue, Markets, Globalization \& Development Review (MGDR) has taken the initiative to bring some of the critical marketing perspectives from Japan to the attention of the research universe outside of Japan. This issue, and another issue planned for later in 2018, will bring selected articles, book reviews, and movie reviews to the global readers of MGDR. Since MGDR is an 'open access' journal, our hope is that the articles from this and the subsequent Japan issue will be downloaded and discussed widely.

In the Japanese marketing academy, there are two or three associations, and parts of the academy are good at employing critical approaches to both studies of marketing management practices and of literature-based theoretical work. Professors on the other hand, rarely recommend to their graduate students to conduct empirical studies employing standard scientific procedures. Rather these professors usually ask them to do holistic and comprehensive reviews of previous studies (mainly journals and readings) which are stored in university archives, ranging in vintage from the early works of Shaw, Copeland, and Alderson (for a review of such early works, see Tadajewski and Jones 2008), to the latest works of 2018.

When young scholars choose this type of study approach, there are mostly literature-based ways open to complete their dissertations; including, of course, adopting a critical approach. It is very rare that Japanese scholars submit their papers to journals publishing in English. Therefore, the authors represented in this (and the subsequent MGDR issue) are glad to have the opportunity to bring some work from Japan to the attention of the world outside Japan.

\section{Articles in this Issue}

Our first article in this special issue, perhaps, is the first introduction to the dominant paradigm in Japanese marketing and distribution academy, which is the biggest academic association in this discipline. This paradigm was influenced greatly, as Usui (2018, in this issue) notes, by the works of Fujiya Morishita. As the contributor of seminal work in the academy, Morishita's thought and frameworks literally held 
unchallenged sway among many Japanese marketing scholars from the 1950 s to the 1970 s.

Morishita's framework was based on Marx's framework of the circulation of capital (Morishita 1969). As is generally known, it described the capital accumulation process through labor exploitation. The primary purpose of his research question was to explore why merchants (commerce) could have yielded surplus (i.e., profit) in equivalent exchange stage of distribution. By this framework, Morishita (1969) was able to depict mainly two critical phenomena in goods distribution. The first one was that it could trace the issue to the socioeconomic problem of distribution in Japan during the period of high economic growth. The second one was that it described fundamental conflict between large-scale enterprises and merchants. This conflicting perspective, while somehow ironical, was suited to the social mood of the 1950-1975 high-growth period. Consumers, and even academicians, believed that large-scale enterprise rampantly dominated consumer markets. The radically inclined became Marx's oracle and believed that only communism could save Japan.

According to Usui's discussion, Morishita's paradigm accomplished its theoretical aims of the period, but later became insufficient as a framework that could capture the more recent and bewildering range of marketing phenomena. Readers will notice that even seminal theoretical work - that had described marketing phenomena for two decades till 1970s and had gained huge academic popularity - fell short when the embedding social context changed.

The second article in this special issue is set in the contemporary period. We believe it provides a typical example about recent critical marketing study in Japan, from a critical angle. Theoretically, the article focuses on an unanticipated consequence approach (unintended actions, in the authors' term). Hidaka and Mizukoshi (2018, in this issue) focus on a social marketing approach, which was launched by the government, under neoliberalism belief, to solve a tax-revenue disparity problem. These authors insist that such interventions to realize individual behavior change and social change, premised on social marketing, should also be the subject of critical analysis.

The authors describe in detail the governmental strategy of "hometown tax", encouraging individuals to direct, voluntary, their tax payments to specific municipalities. The voluntary payer-donors got some tax deductions. The Japanese government introduced this system in 2008 to correct the tax revenue gap between rural municipalities and cities. The initial intention of the Japanese government was to correct the tax revenue gap between rural municipalities and cities through competition among municipalities. In the early stage of its introduction, for five years, this donation system 
did not gain much popularity. After five years, from 2013, the hometown tax (donation) revenues grew rapidly.

The authors explored the reasons and found that some municipalities applied marketing methods to collect donations. They found that, especially from 2013 onwards, the donors would receive not only the tax deduction, but also local specialties as reciprocal gifts. The central government, in turn, issued notices to prevent municipalities from giving excessively luxurious gifts, goods with high exchangeability, and goods that had high value as assets in particular years.

The authors analyze these consequences critically. They note that the hometown tax did not spread widely as the government expected, via the older 'paternalism' approach ('Be good to your townvillage of origin'). Rather, such donations accelerated rapidly accepted when linked to gifts of local specialties. The hometown tax system spread widely through a market approach - especially due to competition among municipalities. Employing Foucault's hegemony concept, they concluded that the neoliberalism, such as paternalism, erodes both industries and consumers and they are both led to act in the hope of achieving (oft-illusory) gains.

The third article in this special issue argues that the media often are meaning-makers. Focusing specifically on fashion magazines, the author found that these magazines not only shaped but also created the symbolic meanings of consumption; indeed, competition across magazines created a symbolic consumption boom. As highlighted in this paper, Suzuki (2108, in this issue) found the process of establishing self-rewarding and self-praising consumption among Japanese women through elaborate textual analysis and translated verbatim quotations from more than 1000 articles in women's magazines. As a theoretical contribution, contrary to McCracken's (1986) argument of division of labor in the consumption meaning system (i.e., creating and disseminating meanings as separate processes), focusing on fashion magazine and Japanese women, Suzuki (2018, in this issue) empirically shows that the women's magazines freed Japanese women from the traditional gender images and roles.

Her discussion is critical in two senses. The first one is that selfpraising consumption was not in accordance with Japanese traditional values. Thus, these media-facilitated acts were rebellious in many ways. The second one is that many actors played roles in establishing the legitimacy of self-praising consumption. Based on her analysis and interpretation, Suzuki teased out and classified at least six categories of such consumption.

The editors expect more interesting discussion in the future about this paper. For example, could this type of consumption be 
acceptable elsewhere in Asia and perhaps in USA and Canada, but perhaps not so acceptable in EU nations? As Schor (1999) showed, some Americans like to buy a lot, even if they did not need the items. In our modern society, most consumption acts require a reason to buy. In contrast to Americans, and - as this contribution shows, in contrast to the self-praising category of consumption in Japan - Europeans tend to show stricter attitudes toward and greater cultural discipline in consumption. We hope this paper may provide the beginning of greater discussion of this theme.

\section{Reviews in this Issue}

In addition to the articles, this issue also has one book review and a media review of a movie genre. Hidaka (2018, in this issue) reviewed the book by Skålén, Fougère and Fellesson (2012), that focuses on the penetration process of the neoliberal managerialism in academic marketing discourse, and a work that has made impacts in academic circles with critical orientations. This type of approach continues the tradition of a critical research agenda established by the works of the Scandinavian marketing scholar (Arndt 1983).

The reviewer - in his book review in this MGDR special issue specifically discusses two issues. The first one is Foucault's "governmentality" concept. With this concept, marketing practice can be regarded as power penetration processes in various managerial behaviors. According to Foucault, even objective scientific knowledge cannot avoid power when it is disseminated. To understand this idea practically, the reviewer tried to trace this concept in the Japanese marketing context. The second issue raised by Hidaka, in this review, is the performative nature of marketing knowledge. Performative view of marketing emphasizes simultaneous description of knowledge and practice (Aroujo, Finch and Kjellberg 2010). This view, indeed, is very close to the modern (non-critical) marketing management view, such as that of Keller (2007), whose quote this reviewer cited: "...branding is not rocket science. In fact, it is an art and a science" (Keller 2007, p. 19). From the critical angle, certain performative knowledge acts sometimes can transcend, even invert, established knowledge based on theoretically-informed practice.

This reviewer introduced some Japanese performative acts related to this book, showing how the performative view upended conventional knowledge. Editorially speaking, it is not clear whether this attempt to portray the performative acts in a critical frame could achieve the reviewer's purpose; indeed, the jury is still out on the critical disruptive aspects of Japanese performative acts discussed in this paper.

The last contribution in this special issue is a media review. Mizukoshi (2018, in this issue) reviews a very famous movie genre, 
especially for the global cult followers of this genre, which includes the films and other media products about 'Ghost in the Shell'. In 2017, in a long-awaited event since 1991 (when the original 'Ghost in the Shell' manga - illustrated book - was published), Hollywood finally made the 'Ghost in the Shell' movie in English, as a live-action film, with Scarlett Johansson as the leading actress. The movie's setting was completely Sci-Fi, after World War-4 in a certain year of the 21 st century. The society was extremely highly connected by neuromancer-style brain jacking into the Net (for those not familiar, with Neuromancer, the book that introduced the term 'cyberspace', see Gibson 1984). People can communicate directly with each other, across space, by the neuromancer-style connections. Despite the long-running cult following of this genre, and the great success of the original manga and Japanese anime film, the Hollywood live-action film was a box office failure.

There have been already a lot of reviews of this film genre. Mizukoshi (2018), in this MGDR contribution, focuses on the westernized "structure of myths," the common structure of the Scandinavian saga, Indian narrative story, even Russian formalism (Propp 1928).

Mizukoshi questions the universality of this structure of myths. The reviewer feels that Rupert Sanders - the director of the Hollywood version - might have held too tightly to this Western-mythical view of reincarnation-rebirth, and hence created a film narrative that was not very appealing. According to reviewer, Sanders defined Motoko (the leading actress, Scarlett Johansson) as a type of Robocop. This meant that the story in this case (the Hollywood version) simplified her crisis a driving force in the 'Ghost in the Shell' series of products. Instead of the great ambiguity of human-machine, female-cyborg that the fans loved, in the English version her quest becomes to regain humanness, from a Robocop version.

Compared to the latest Hollywood movie, this reviewer finds that the original Japanese manga and anime movie had represented pantheism. In pantheism, we cannot separate the physical body from the identity. Only the ghost is beyond pantheism, thus, this movie focused on the ghost, according to this reviewer's opinion. This is a rare movie (taken as a set, of all 'Ghost' products) where the mutual East-West influences are strong and philosophically significant; and the Western and the Eastern reactions are quite different. That, of course, is representative of the diversity of contemporary globalization.

\section{Concluding Comment}

The editors of the MGDR and of the special issue hope that this (and the follow-up Japan issue, later in this volume of MGDR) would launch some discussion on critical approaches from marketing and 
consumption emanating from Japan, at this juncture and in the past. Forums for comments are already available on portals such as ResearchGate and Facebook.

\section{References}

Arndt, Johan (1983), "The Political Economy Paradigm: Foundation for Theory Building in Marketing," Journal of Marketing, 47 (4), 4454. http://dx.doi.org/10.2307/1251398

Aroujo, Louis, John Finch and Hans Kjellberg (2010), Reconnecting Marketing to Markets. Oxford University Press.

Foucault, Michel (2000b), "The Subject and Power," in Power: The Essential Works of Foucault, Vol. 3, James D. Faubion, ed. Free Press, 326-48.

Gibson, William (1984), Neuromancer. New York: Berkley Publishing Division of Penguin Putnam.

Hidaka, Yuichiro (2018), "Book Review, Skålén, Per, Martin Fougère, and Markus Fellesson (2010), Marketing Discourse: A Critical Perspective (2012)", Markets, Globalization \& Development Review, 3 (1), Special Issue, Article 4. https://doi.org/10.23860/MGDR-2018-03-01-05

Hidaka, Yuichiro and Kosuke Mizukoshi (2018), " From Social Marketing to Societal Perversion: History of Hometown Tax in Japan," Markets, Globalization \& Development Review, 3 (1), Special Issue, Article 2. https://doi.org/10.23860/MGDR-201803-01-03

Keller, Kevin L. (2007), Strategic Brand Management, Third Edition. New York: Prentice Hall.

McCracken, Grant (1986), "Culture and Consumption: A Theoretical Account of the Structure and Movement of the Cultural Meaning of Consumer Goods," Journal of Consumer Research, 13 (1), 71-84. https://doi.org/10.1086/209048

Mizukoshi, Kosuke (2018), "Ghost in the Shell," Markets, Globalization \& Development Review, 3 (1), Special Issue, Article 5. https://doi.org/10.23860/MGDR-2018-03-01-06

Propp, Vladimir Y. (1928), Russian Heroic Epic Poetry, in Vladimir Propp, Theory and History of Folklore. Anatoly Liberman, ed. Manchaster, Manchester University Press, 149-64.

Schor, Juliet B. (1999), The Overspent American: Why We Want What We Don't Need. New York, NY: Harper Perennial. 
Suzuki, Satoko (2018), "Revisiting the Creation of Meaning by Media: A Perspective from Japan," Markets, Globalization \& Development Review, 3 (1), Special Issue, Article 3. https://doi.org/10.23860/MGDR-2018-03-01-04

Tadajewski, Mark, and Donald Gordon Brian Jones, eds. (2008), History of Marketing Thought, Vol. 1, 2 \& 3, Thousand Oaks, CA: Sage.

Usui, Kazuo (2018), "Legacy of Critical Marketing in Japan: Rise and Fall of Morishita's Paradigm," Markets, Globalization \& Development Review, 3 (1), Special Issue, Article 1. https://doi.org/10.23860/MGDR-2018-03-01-02 